Faculty of Agronomy, Czech University of Agriculturc, Prague, Czech Republic', Faculty of Agriculture and Horticulture, Humboldt University of Berlin, Berlin, Germany ${ }^{2}$ and National Stud of Kladruby nad Labem, Research Department Slatinany, Czech Republic ${ }^{3}$

VÁCLAV JAKUBEC ${ }^{1}$, WERNER SCHLOTE ${ }^{2}$, JAROSLAV JELÍNEK ${ }^{3}$, ARMIN SCHOLZ ${ }^{2}$ and NORBERT ZÁLIS ${ }^{3}$

\title{
Linear type trait analysis in the genetic resource of the Old Kladrub Horse
}

\begin{abstract}
Summary
Linear type evaluations of 214 horses of the Old Kladrub breed for 32 traits were used to analyse the effect of variety (gray and black), sex (stallions and mares) and age. The linear model included the fixed effects of variety, sex and age and interactions variety $\mathrm{x}$ sex, variety $\mathrm{x}$ age and sex $\mathrm{x}$ age. Significant differences were found between the varieties in almost two thirds of the traits. The topline was longer and weaker in the black variety than in the gray one. The shoulder of the gray horses was longer and more sloped than of the black one. The animals of the gray variety had a wider and deeper chest. The stance of forelimbs and hind limbs was more correct in the gray variety than in the black one. Significant differences between sexes were observed in a few traits. Only 12 of 32 traits showed significant changes with age. In 10 of 32 traits, at least one of the interactions was significant. The estimates of this study characterise the Old Kladrub breed and its varieties in its current state and allow for more accurate evaluation of the horses.
\end{abstract}

Key words: Old Kladrub Horse, linear type traits, classification, varieties, sex, age

\section{Zusammenfassung}

Titel der Arbeit: Analyse der linearen Exterieurmerkmale in der Genreserve des Altkladruber Pferdes Lineare Exterieurbeurteilungen von 214 Pferden der Altkladruber Rasse für 32 Merkmale wurden herangezogen, um den Einfluss der Varietät (Grauschimmel und Rappen), des Geschlechts (Hengste und Stuten) und des Alters zu untersuchen. In dem linearen Modell für die Analyse wurden die fixen Effekte der Varietät, des Geschlechts und des Alters sowie die einfachen Wechselwirkungen zwischen Varietät und Geschlecht, Varietät und Alter sowie Geschlecht und Alter berücksichtigt. Signifikante Unterschiede zwischen den Varietäten wurden bei fast zwei Dritteln aller Merkmale festgestellt. Die Rückenlinie der Rappen war länger und weniger fest als bei den Grauschimmeln. Die Schulter der Grauschimmel war länger und schräger (stärker geneigt) als bei den Rappen. Sie hatten auch eine breitere und tiefere Brust. Die Stellung der Vorder- und Hinterbeine war bei den Grauschimmeln ebenfalls korrekter als bei den Rappen. Signifikante Unterschiede zwischen den Geschlechtern wurden nur für wenige Merkmale gefunden. Lediglich bei 12 der 32 Merkmale fanden sich deutliche Veränderungen zwischen den Altersklassen. In 10 der 32 Merkmale war mindestens eine der einfachen Wechselwirkungen signifikant. Die Schätzwerte aus der vorliegenden Untersuchung kennzeichnen die Altkladruber Rasse und ihre beiden Varietäten in ihrem gegenwärtigen Stand und ermöglichen eine genauere Bewertung der Pferde.

Schlüsselwörter: Altkladruber Pferd, lineare Exterieurmerkmale, Klassifizierung, Varietäten, Geschlecht, Alter

\section{Introduction}

The oldest lines of the Old Kladrub Horse were founded at the end of the 18th and at the beginning of the 19th century. Therefore it is an important genetic resource of horses not only on the scale of the Czech Republic and Europe, but also worldwide. 
The Old Kladrub Horse is a heavy coach horse and one of the largest breeds of warmblood horses, strong, kind, with short strides and high knee action. It is described as showing a noble head with a convex face, a muscular and crested neck and sloped shoulders. The body is long and shallow, the hindquarters are rounded and muscular and the limbs are clean. The extraordinary type and the specific external traits of this breed should be saved for the next generations. It is evident that for such a specific coach horse the breeding objective must be focussed on the external type traits. Due to imperial tradition, the breed consists of a gray and a black variety.

Therefore in 1995, a new linear type trait classification system was developed for the Old Kladrub Horse (JAKUBEC et al., 1995).The integral parts of this system are the description of colour and marks, the description of linear type traits and body conformation failures as well as the aggregate evaluation of type, sex expression, frame, bulkiness, conformation, nobleness, harmony and gaits. This system is based on linear type trait classification systems for horses which were proposed by several authors and partly introduced into breeding schemes (MAHRARENS and SCHERTLER, 1987; HOLMSTRÖM et al., 1990; SWALVE and FLÖCK, 1990; PREISINGER et al., 1991; WEYMANN, 1992; VAN BERGEN and VAN ARENDONK, 1993; HARTMANN et al., 1994; KOENEN et al., 1994). As a prerequisite for developing a breeding plan the type traits were recorded in the studs of Kladruby nad Labem and Slatiňany. In the present investigation these records were to be used for estimating phenotypic parameters of the Old Kladrub population and for analysing variation between effects of variety, sex, age and their interactions.

\section{Material and Methods}

The population of Old Kladrub horses is mainly concentrated in the studs of Kladruby nad Labem (gray variety) and Slatiňany (black variety) in Eastern Bohemia. The black variety experienced a dramatic sell-out in the 1930's, and it was not before 1940 that the animals could be gathered again in Slatinany (BÍLEK, 1955). After the recovery of the black population (DUŠEK, 1992) both varieties together consist now of about 30 stallions and 250 mares. The gray variety is organized in 5 sire lines and 11 mare families and the black variety in 4 sire lines and 14 mare families, respectively.

A committee of three skilled horse classifiers described 214 stallions and mares of the gray and black variety aged between 3 and 25 years at the National stud of Kladruby in November 1995. The classifiers used a scale of 1 to 9 points for the 32 linear type traits with increments of one point, where the parameters represented the extremes in the biological variation (Table 1).

All traits were analysed by least-squares analysis using the GLM procedure (SAS, 1995). The linear model included the main effects variety, sex, age class and their first order interactions:

$\mathrm{Y}_{\mathrm{ijk} \mathrm{k}}=\mu+\mathrm{VAR}_{\mathrm{i}}+\mathrm{SEX}_{\mathrm{j}}+\mathrm{AGE}_{\mathrm{k}}+\left(\mathrm{VARXSEX}_{\mathrm{ij}}+\left(\mathrm{VARXAGE}_{)_{\mathrm{ik}}}+(\operatorname{SEXXAGE})_{\mathrm{jk}}+\mathrm{e}_{\mathrm{ijk} \mathrm{k}}\right.\right.$, where:

$\mathrm{Y}_{\mathrm{ijkl}} \quad$ = observation of a linear type trait, 


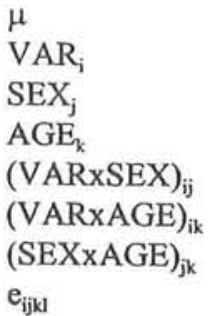

Table 1

Description of the traits of the linear scoring system (Beschreibung der Merkmale im linearen Bewertungssystem)

\begin{tabular}{|c|c|c|}
\hline \multirow[t]{2}{*}{ Trait } & \multicolumn{2}{|c|}{ Scores } \\
\hline & 1 & 9 \\
\hline \multicolumn{3}{|l|}{ Front } \\
\hline 1. Height at withers & low & high (transformed from measured values) \\
\hline 2. Head profile & concave & convex \\
\hline 3. Neck length & long & short \\
\hline 4. Neck tethering & low & high \\
\hline 5. Neck topside & concave & convex \\
\hline 6. Withers length & short & long \\
\hline 7. Withers height & low & high \\
\hline \multicolumn{3}{|l|}{ Body } \\
\hline 8. Topline length & short & long \\
\hline 9. Topline vault & weak & straight \\
\hline 10. Loin length & short & long \\
\hline 11. Loin vault & weak & straight \\
\hline 12. Shoulder length & short & long \\
\hline 13. Shoulder slope & straight & sloping \\
\hline 14. Chest girth & low & high (transformed from measured values) \\
\hline 15. Chest length & short & long \\
\hline 16. Chest width & narrow & broad \\
\hline 17. Chest depth & shallow & deep \\
\hline 18. Breast width & narrow & broad \\
\hline \multicolumn{3}{|l|}{ Rear } \\
\hline 19. Croup length & short & long \\
\hline 20. Croup width & narrow & broad \\
\hline 21. Croup shape & sloping & straight \\
\hline 22. Croup profile (back view) & roofy & vaulty \\
\hline 23. Tail tethering & low & high \\
\hline \multicolumn{3}{|l|}{ Limbs } \\
\hline 24. Forelimbs - front view & narrow & broad \\
\hline 25. Forelimbs - side view & back at the knee & over the knee \\
\hline \multicolumn{3}{|l|}{ 26. Bulkiness- cannon bone } \\
\hline circumference & low & high (transformed from measured values) \\
\hline 27. Foretoes - side view & sloping & weak \\
\hline 28. Forehoof - side view & sloping & weak \\
\hline 29. Forehoof width & narrow & broad \\
\hline 30. Forehoof size & small & large \\
\hline 31. Hind limbs - side view & sickle hocked & straight \\
\hline 32. Hind limbs - back view & narrow & broad \\
\hline
\end{tabular}

$=$ overall mean,

$=$ fixed effect of the $i$-th variety,

$=$ fixed effect of the $j$-th sex,

$=$ fixed effect of the $k$-th age class,

$=$ fixed effect of the $i j$-th interaction between variety and sex,

$=$ fixed effect of the $i k$-th interaction between variety and age,

$=$ fixed effect of the $j k$-th interaction between sex and age,

$=$ random residual error. 
The distribution of animals among the classes was quite unbalanced, in particular for sex and age (Table 2). Therefore the age classes were composed also with respect to their frequency.

Table 2

Distribution of animals for variety, sex and age (Verteilung der Tiere nach Varietät, Geschlecht und Alter)

\begin{tabular}{lccccccccccc}
\hline $\begin{array}{l}\text { Effect } \\
\text { Class }\end{array}$ & \multicolumn{2}{c}{ Variety } & \multicolumn{1}{c}{ Sex } & \multicolumn{7}{c}{ Age class } \\
& Gray & Black & Males & Females & $\begin{array}{c}1 \\
2\end{array}$ & $\begin{array}{c}3 \\
4\end{array}$ & 5 & 6 & 7 \\
\hline $\begin{array}{l}\text { Number } \\
\text { of animals }\end{array}$ & 113 & 101 & 62 & 152 & 45 & 27 & 48 & 33 & 22 & 15 & 24 \\
\hline
\end{tabular}

\section{Results and Discussion}

In general, the scale of the linear type scores describes the whole range of the possible phenotypic expressions of the trait considered across populations. Therefore, the estimates of the overall means and standard deviations (Table 2) should characterise the specific properties and variation of the Old Kladrub population in its current state. For about half of the traits, considerable deviations ( 0.7 to 1.5 points) from the expected average of five points were observed. The elevated values for the two transformed traits of chest girth and bulkiness indicate that the transformed values had been adjusted to constants different from the overall mean. Thus a reassessment of the transformation should be considered. The other major deviations suggest that the Old Kladrub Horse had high neck tethering, short and straight shoulders, wide croup, high tail tethering as well as sloping foretoes and forehoofs and slightly bended hind limbs all viewed from the side. One of the typical characteristics of the Old Kladrub Horse, the convex head profile, was not as clearly evident from the estimates as might have been expected. However, it is not clear whether the reason was a certain bias of the classifiers towards the breed or a change in the population caused by the introduction of some sire lines from other populations decades ago.

With respect to the variation of the linear type scores, using the scoring scale and assuming approximately normal distribution, a standard deviation of about 1.0 to 1.3 points was to be expected. For most of the traits, the estimates lay within this range or quite close. However, for neck tethering, topline vault, shoulder length, shoulder shape and forehoof (sideview) the standard deviation estimate was considerably lower. Either the scale was not fully exhausted by the classifiers or the variation is in fact reduced in the population for these traits. The considerably higher values for the standard deviation of chest girth, height at withers as well as of head and croup profile can only be attributed to a skewed distribution of the values and /or the trait in the population.

The highest interest lies in the differences of the linear type traits between the gray and the black variety. Highly significant differences between both varieties were found in almost two thirds of the traits (Table 3). Among the seven traits of the front only height at withers and head profile did not show significant differences between the varieties. This indicates that the most obvious characteristic of the Old Kladrub Horse, the 
convex face, was equally developed in both varieties. For the other traits with the exception of neck tethering higher scores were observed in the gray variety. Thus, gray horses in particular have longer neck and longer and higher withers than black horses.

Table 3

Overall means, standard deviations (SD) and coefficients of variation (CV) of linear trait scores and least squares means (LSM) and standard errors (SE) for the varieties [Allgemeine Mittelwerte, Standardabweichungen (SD) und Variationskoeffizienten (CV) für die linearen Exterieurmerkmale und Least squares-Mittelwerte (LSM) und Standardfehler (SE) für die Varietäten]

\begin{tabular}{|c|c|c|c|c|c|c|c|c|}
\hline \multirow[t]{3}{*}{ Trait } & \multirow{2}{*}{\multicolumn{3}{|c|}{ Population }} & \multicolumn{4}{|c|}{ Variety } & \multirow{3}{*}{$\begin{array}{l}\text { Level of } \\
\text { significance }\end{array}$} \\
\hline & & & & Gray & & Bla & & \\
\hline & Mean & SD & $\mathrm{CV}(\%)$ & LSM & SE & LSM & SE & \\
\hline \multicolumn{9}{|l|}{ Front } \\
\hline 1. Height at withers & 5.36 & 1.74 & 32.48 & 5.44 & 0.26 & 5.80 & 0.27 & \\
\hline 2.Head profile & 5.38 & 1.59 & 29.48 & 5.31 & 0.24 & 5.46 & 0.25 & \\
\hline 3.Neck length & 4.92 & 1.03 & 21.00 & 5.59 & 0.15 & 4.50 & 0.16 & ** \\
\hline 4.Neck tethering & 6.22 & 0.77 & 12.34 & 6.21 & 0.11 & 6.63 & 0.12 & $* *$ \\
\hline 5.Neck topside & 5.07 & 1.44 & 28.34 & 5.89 & 0.21 & 4.96 & 0.26 & $* *$ \\
\hline 6. Withers length & 4.45 & 1.01 & 22.65 & 5.02 & 0.15 & 4.01 & 0.16 & $*$ \\
\hline 7.Withers height & 4.39 & 1.04 & 23.65 & 4.75 & 0.15 & 4.02 & 0.16 & $* *$ \\
\hline \multicolumn{9}{|l|}{ Body } \\
\hline 8.Topline length & 5.55 & 1.00 & 18.03 & 5.35 & 0.15 & 5.73 & 0.16 & * \\
\hline 9.Topline vault & 4.31 & 0.70 & 16.19 & 4.55 & 0.10 & 3.99 & 0.11 & ** \\
\hline 10.Loin length & 5.76 & 1.13 & 19.62 & 5.75 & 0.17 & 5.72 & 0.18 & \\
\hline 11.Loin vault ${ }^{1}$ & 4.85 & 0.94 & 19.34 & 4.90 & 0.14 & 5.25 & 0.15 & * \\
\hline 12.Shoulder length & 3.81 & 0.63 & 16.56 & 4.17 & 0.09 & 3.46 & 0.10 & ** \\
\hline 13.Shoulder slope & 3.83 & 0.62 & 16.16 & 4.19 & 0.09 & 3.40 & 0.10 & *** \\
\hline 14.Chest girth & 6.51 & 2.17 & 33.32 & 6.39 & 0.32 & 6.82 & 0.34 & \\
\hline 15. Chest length & 5.89 & 0.98 & 16.57 & 5.89 & 0.14 & 5.89 & 0.15 & \\
\hline 16. Chest width' & 5.16 & 1.06 & 20.56 & 5.64 & 0.16 & 4.60 & 0.17 & ** \\
\hline 17.Chest depth & 5.41 & 1.07 & 19.84 & 5.64 & 0.16 & 4.99 & 0.17 & ** \\
\hline 18. Breast width & 5.14 & 1.09 & 21.16 & 5.57 & 0.16 & 4.55 & 0.17 & ** \\
\hline \multicolumn{9}{|l|}{ Rear } \\
\hline 19. Croup length & 4.28 & 0.80 & 18.66 & 4.36 & 0.12 & 4.35 & 0.13 & \\
\hline 20.Croup width & 5.91 & 0.92 & 15.70 & 6.04 & 0.14 & 5.85 & 0.15 & \\
\hline 21.Croup shape & 4.56 & 0.91 & 19.94 & 4.65 & 0.13 & 4.79 & 0.14 & \\
\hline 22.Croup profile & 5.48 & 1.76 & 32.23 & 5.87 & 0.26 & 5.67 & 0.28 & \\
\hline 23.Tail tethering & 5.92 & 1.26 & 38.10 & 6.00 & 0.19 & 6.14 & 0.20 & \\
\hline \multicolumn{9}{|l|}{ Limbs } \\
\hline 24.Forelimbs-front $v .^{\prime}$ & 5.20 & 1.08 & 20.75 & 5.59 & 0.16 & 4.63 & 0.17 & $\pitchfork *$ \\
\hline 25.Forelimbs-side v. ${ }^{\prime}$ & 4.20 & 1.21 & 28.86 & 4.81 & 0.18 & 4.00 & 0.19 & ** \\
\hline \multicolumn{9}{|l|}{ 26. Bulkiness-cannon } \\
\hline bone circumf. & 6.28 & 1.26 & 20.16 & 6.28 & 0.19 & 6.31 & 0.20 & \\
\hline 27.Foretoes-side view & 3.97 & 0.82 & 20.57 & 4.17 & 0.12 & $3: 61$ & $0: 13$ & ** \\
\hline 28.Forehoof-side view & 4.22 & 0.76 & 17.96 & 4.45 & 0.11 & 4.02 & 0.12 & ** \\
\hline 29.Forehoof width ${ }^{2}$ & 4.75 & 0.82 & 17.29 & 4.95 & 0.12 & 4.23 & 0.13 & ** \\
\hline 30.Forehoof size 2 & 4.61 & 0.90 & 19.57 & 4.93 & 0.13 & 4.13 & 0.14 & ** \\
\hline 31.Hind limbs-side v. & 3.68 & 0.99 & 26.86 & 3.97 & 0.15 & 3.23 & 0.16 & ** \\
\hline 32.Hind limbs-back v. ${ }^{3}$ & 5.12 & 0.87 & 16.98 & 5.12 & 0.13 & 4.96 & 0.14 & \\
\hline
\end{tabular}

1) $\left.\left.n=213,{ }^{2}\right) n=212,{ }^{3}\right)=211$;

Error probability: $\bullet \mathrm{P}<0.05$, $\bullet \mathrm{P}<0.01$

For body traits, eight of eleven showed significant and highly significant differences between between both varieties. The topline is longer and its vault weaker in the black 
variety than in the gray one. On the other hand the loin vault is weaker in the gray one. Interestingly, there were no differences in the chest girth of both varieties. The shoulder of the gray horses is longer and more sloped than of the black ones. A positive genetic correlation of a long sloping shoulder with dressage was observed in Dutch Warmblood Riding horses (KOENEN et al., 1994). Various authors came to the conclusion that a longer shoulder provides a greater base for the long muscles and a more sloping shoulder facilitates the forward and upward movement of the limb during the first part of the swing phase.This would indicate a higher knee action in the black variety than in the gray one. An answer to this question might be possible by the analysis of the knee action in the Old Kladrub Horse and the analysis of phenotypic and genetic correlations between shoulder length and shape on the one hand and knee action on the other hand. In the gray variety the chest was markedly deeper and chest and breast much wider than in the black one.

Significant differences between varieties were not detected for any trait of the rear. However, a long sloping croup seems to be favourably correlated with movement traits (KOENEN et al., 1994). The analysis of the limbs showed no differences between both varieties in the cannon bone circumference which should be a characteristic of bulkiness and in the hind limbs (back view). In the gray variety the stance of the forelimbs (front view) was wider and more correct (forelimbs-side view) than in the black one. The foretoes and forehoofs from the side were in the black variety more sloped than in the gray one.The gray horses had larger forehoofs and more correct stance of hind limbs (side view) than the black horses.

The measured traits had already been corrected for sex when transformed to the point scale. Therefore, the absence of differences between the two sexes for these traits (Table 4) was expected. However, it was suprising to find highly significant or significant differences only in few of the other traits. The stallions showed a higher neck connection with the body and a more convex neck topside than the mares. The chest of the mares was markedly deeper than the chest of the stallions and their croup was more sloped than in stallions.

Table 5 shows the effect of age on the linear type traits. In 12 of 32 traits significant or highly significant differences were found between age classes. Among the front traits, height at withers, withers height and neck length increased with age class. The neck topside showed also marked differences from concave shape in younger age to convex in higher age classes.The topline was straight in the young horses and weaker in the old horses. Chest girth, chest depth as well as croup width were traits which obviously increased with age. It is also worth mentioning that the croup changed with age from the roofy type to the vaulty type. The cannon bone circumference and forehoof width increase with age. Head profile, shoulder shape and croup shape are profile or shape traits, which seem to be constant during the life. Also most of the other traits showed only slight differences for age.

In Table 6 only those traits are specified, for which at least one significant or highly significant interaction was found. However, no specific pattern or logic relation 
Table 4

Least squares means (LSM) and standard errors (SE) of linear trait scores for sex [Least-squares-Mittelwerte (LSM) und Standardfehler (SE) der linearen Exterieurmerkmale für die Geschlechter]

\begin{tabular}{|c|c|c|c|c|c|}
\hline \multirow[t]{3}{*}{ Trait } & \multicolumn{4}{|c|}{ Sex } & \multirow{3}{*}{$\begin{array}{c}\text { Level of } \\
\text { significance }\end{array}$} \\
\hline & \multicolumn{2}{|c|}{ Stallions } & \multicolumn{2}{|c|}{ Mares } & \\
\hline & LSM & SE & LSM & SE & \\
\hline \multicolumn{6}{|l|}{ Front } \\
\hline 1.Height at withers & 5.65 & 0.39 & 5.59 & 0.15 & \\
\hline 2.Head profile & 5.40 & 0.36 & 5.38 & 0.14 & \\
\hline 3.Neck length & 5.14 & 0.23 & 4.95 & 0.09 & \\
\hline 4.Neck tethering & 6.70 & 0.17 & 6.15 & 0.07 & ** \\
\hline 5.Neck topside & 5.76 & 0.33 & 5.09 & 0.13 & 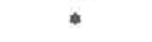 \\
\hline 6.Withers length . & 4.58 & 0.23 & 4.45 & 0.09 & \\
\hline 7.Withers heigth & 4.36 & 0.24 & 4.41 & 0.09 & \\
\hline \multicolumn{6}{|l|}{ Body } \\
\hline 8.Topline length & 5.47 & 0.23 & 5.61 & 0.09 & \\
\hline 9.Topline vault & 4.27 & 0.16 & 4.26 & 0.06 & \\
\hline 10.Loin length & 5.53 & 0.26 & 5.93 & 0.10 & \\
\hline 11.Loin vault ${ }^{\prime}$ & 5.26 & 0.21 & 4.89 & 0.08 & \\
\hline 12.Shoulder length & 3.80 & 0.14 & 3.83 & 0.06 & \\
\hline 13.Shoulder slope & 3.80 & 0.14 & 3.79 & 0.06 & \\
\hline 14.Chest girth & 6.41 & 0.49 & 6.80 & 0.19 & \\
\hline 15.Chest length & 5.84 & 0.22 & 5.95 & 0.09 & \\
\hline 16. Chest width' & 5.05 & 0.24 & 5.19 & 0.09 & \\
\hline 17.Chest depth & 5.01 & 0.24 & 5.63 & 0.10 & $*$ \\
\hline 18.Breast width & 4.93 & 0.25 & 5.19 & 0.10 & \\
\hline \multicolumn{6}{|l|}{ Rear } \\
\hline 19.Croup length & 4.31 & 0.18 & 4.40 & 0.07 & \\
\hline 20.Croup width & 5.80 & 0.21 & 6.08 & 0.08 & \\
\hline 21.Croup shape & 4.94 & 0.21 & 4.50 & 0.08 & * \\
\hline 22.Croup profile & 6.12 & 0.40 & 5.42 & 0.16 & \\
\hline 23.Tail tethering ${ }^{\prime}$ & 6.28 & 0.28 & 5.86 & 0.11 & \\
\hline \multicolumn{6}{|l|}{ Limbs } \\
\hline 24.Forelimbs - front view ${ }^{1}$ & 4.98 & 0.24 & 5.24 & 0.10 & \\
\hline 25.Forelimbs - side view ${ }^{1}$ & 4.62 & 0.27 & 4.10 & 0.11 & \\
\hline \multicolumn{6}{|l|}{ 26. Bulkiness- cannon bone } \\
\hline circumference & 6.19 & 0.29 & 6.40 & 0.11 & \\
\hline 27.Foretoes - side view & 3.80 & 0.18 & 3.98 & 0.07 & \\
\hline 28.Forehoof -.side view & 4.19 & 0.17 & 4.28 & 0.07 & \\
\hline 29.Forehoof width ${ }^{2}$ & 4.49 & 0.19 & 4.70 & 0.07 & \\
\hline 30.Forehoof size ${ }^{2}$ & 4.58 & 0.20 & 4.47 & 0.08 & \\
\hline 31.Hind limbs - side view & 3.46 & 0.22 & 3.74 & 0.09 & \\
\hline 32. Hind limbs - back view ${ }^{3}$ & 4.99 & 0.20 & 5.09 & 0.07 & \\
\hline
\end{tabular}

$\left.\left.n=213,{ }^{2}\right) n=212,5\right) n=21$

Error probability: ${ }^{\circ} \mathrm{P}<0.05, * \bullet \mathrm{P}<0.01$

between significant first order interactions could be observed.

The horses included in this analysis constitute the nucleus and the larger part of the population of the Old Kladrub breed. Only in this nucleus breeding stallions are produced. The results can be considered as describing the current status of this genetic resource and can be used for controlling its development in the future. However, one must also remember that even using the linear description of these type traits, they are still subjective scores and therefore open to latent changes of the scale. Also, in this investigation combined scores were given by the group of classifiers, so variation 
Table 5

Least squares means (LSM) and standard errors (SE) of linear trait scores for age [Least squares-Mittelwerte (LSM) und Standardfehler (SE) der linearen Exterieurmerkmale für das Alter]

Trait

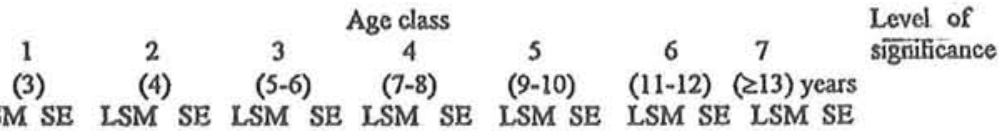

LSM SE LSM SE LSM SE LSM SE LSM SE LSM SE LSM SE

\section{Iront}

1.Height at withers

2.Head profile

3.Neck length

4.Neck tcthering

5.Neck topside

6.Withers length

7.Withers height

Body

8.Topline length

9.Topline vault

10.Loin length

11. Loin vault'

12. Shoulder length

13. Shoulder slope

14.Chest girth

15. Chest length

16. Chest width ${ }^{1}$

17. Chest depth

18. Breast width

Rear

19. Croup length

20.Croup width

21.Croup shape

22. Croup profile

23.Tail tethering ${ }^{\prime}$

Limbs

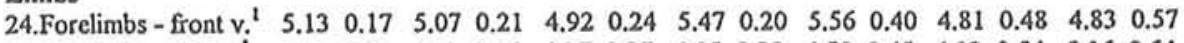

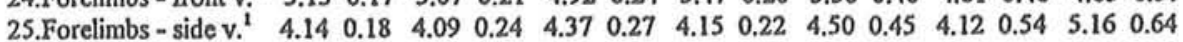
26.Bulkiness- cannon

bone circumf.

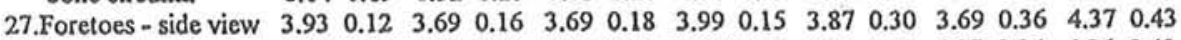

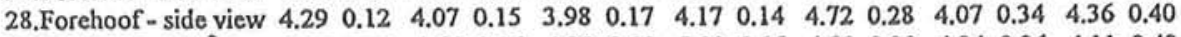
$\begin{array}{lllllllllllllll}\text { 29. Forehoof } \text { width }^{2} & 4.92 & 0.13 & 4.64 & 0.16 & 4.28 & 0.18 & 5.00 & 0.15 & 4.88 & 0.30 & 4.34 & 0.36 & 4.11 & 0.43\end{array}$

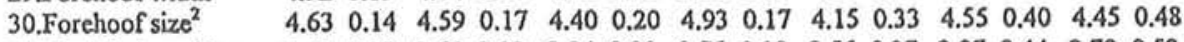

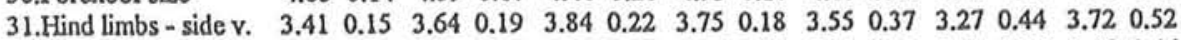
$\begin{array}{lllllllllllllll}32 . H \text { lind limbs -back v. } & 4.85 & 0.13 & 5.03 & 0.18 & 5.02 & 0.19 & 5.17 & 0.16 & 5.61 & 0.32 & 5.17 & 0.38 & 4.45 & 0.46\end{array}$

$\begin{array}{llllllllllllll}4.84 & 0.27 & 5.42 & 0.34 & 5.03 & 0.38 & 7.13 & 0.32 & 5.97 & 0.64 & 6.23 & 0.77 & 4.72 & 0.92\end{array}$ $\begin{array}{llllllllllllll}5.33 & 0.24 & 5.75 & 0.31 & 5.21 & 0.35 & 5.58 & 0.29 & 5.84 & 0.58 & 5.28 & 0.70 & 4.69 & 0.84\end{array}$ $\begin{array}{llllllllllllll}4.54 & 0.15 & 4.66 & 0.20 & 4.95 & 0.23 & 5.43 & 0.19 & 5.52 & 0.38 & 4.79 & 0.46 & 5.43 & 0.54\end{array}$ $\begin{array}{lllllllllllllll}6.25 & 0.12 & 6.49 & 0.15 & 6.19 & 0.17 & 6.44 & 0.14 & 6.36 & 0.28 & 6.83 & 0.34 & 6.41 & 0.40\end{array}$ $\begin{array}{llllllllllllll}4.41 & 0.22 & 4.53 & 0.27 & 5.50 & 0.32 & 5.71 & 0.27 & 6.17 & 0.53 & 4.96 & 0.64 & 6.69 & 0.76\end{array}$ $\begin{array}{llllllllllllll}4.32 & 0.15 & 4.39 & 0.20 & 4.27 & 0.22 & 4.64 & 0.19 & 4.76 & 0.37 & 4.89 & 0.45 & 4.34 & 0.53\end{array}$ $\begin{array}{llllllllllllll}3.83 & 0.16 & 4.23 & 0.20 & 4.16 & 0.23 & 4.65 & 0.19 & 4.63 & 0.39 & 4.47 & 0.46 & 4.71 & 0.55\end{array}$

$\begin{array}{llllllllllllll}5.76 & 0.15 & 5.79 & 0.19 & 5.37 & 0.22 & 5.41 & 0.18 & 5.66 & 0.37 & 5.25 & 0.44 & 5.53 & 0.52\end{array}$ $\begin{array}{llllllllllllll}4.53 & 0.11 & 4.38 & 0.14 & 4.34 & 0.15 & 4.43 & 0.13 & 4.42 & 0.26 & 3.91 & 0.31 & 3.85 & 0.37\end{array}$ $\begin{array}{llllllllllllll}5.90 & 0.17 & 5.84 & 0.22 & 5.50 & 0.25 & 5.59 & 0.21 & 6.02 & 0.42 & 5.96 & 0.50 & 5.32 & 0.60\end{array}$ $\begin{array}{llllllllllllll}4.81 & 0.14 & 5.07 & 0.18 & 4.85 & 0.21 & 4.77 & 0.17 & 5.20 & 0.35 & 5.62 & 0.44 & 5.20 & 0.49\end{array}$ $\begin{array}{llllllllllllll}3.56 & 0.10 & 3.66 & 0.12 & 3.72 & 0.14 & 3.89 & 0.12 & 4.08 & 0.23 & 3.57 & 0.29 & 4.20 & 0.33\end{array}$ $\begin{array}{llllllllllllll}3.79 & 0.09 & 3.75 & 0.12 & 3.84 & 0.14 & 3.85 & 0.11 & 3.92 & 0.23 & 3.75 & 0.27 & 3.66 & 0.33\end{array}$ $\begin{array}{lllllllllllllll}5.47 & 0.33 & 5.93 & 0.42 & 5.96 & 0.48 & 7.91 & 0.40 & 5.92 & 0.81 & 6.77 & 0.96 & 8.26 & 1.14\end{array}$ $\begin{array}{llllllllllllll}5.70 & 0.15 & 5.59 & 0.19 & 5.82 & 0.22 & 6.23 & 0.18 & 5.85 & 0.36 & 5.66 & 0.43 & 6.39 & 0.51\end{array}$ $\begin{array}{llllllllllllll}5.11 & 0.16 & 4.98 & 0.21 & 4.90 & 0.23 & 5.43 & 0.20 & 5.53 & 0.39 & 5.01 & 0.49 & 4.87 & 0.56\end{array}$ $\begin{array}{llllllllllllll}4.48 & 0.16 & 4.91 & 0.21 & 5.14 & 0.24 & 5.55 & 0.20 & 5.63 & 0.40 & 5.26 & 0.47 & 6.26 & 0.57\end{array}$ $\begin{array}{lllllllllllllll}5.01 & 0.17 & 4.86 & 0.21 & 4.94 & 0.24 & 5.44 & 0.20 & 5.58 & 0.40 & 4.76 & 0.48 & 4.83 & 0.57\end{array}$

$\begin{array}{llllllllllllll}4.08 & 0.12 & 4.07 & 0.15 & 4.28 & 0.18 & 4.55 & 0.15 & 4.71 & 0.30 & 4.01 & 0.35 & 4.77 & 0.42\end{array}$ $\begin{array}{llllllllllllll}5.47 & 0.14 & 5.54 & 0.18 & 6.01 & 0.20 & 6.19 & 0.17 & 6.19 & 0.34 & 6.34 & 0.41 & 5.86 & 0.49\end{array}$ $\begin{array}{llllllllllllll}4.51 & 0.14 & 4.43 & 0.18 & 4.65 & 0.20 & 4.64 & 0.17 & 4.83 & 0.34 & 4.29 & 0.40 & 5.69 & 0.48\end{array}$ $\begin{array}{llllllllllllll}4.49 & 0.27 & 5.46 & 0.34 & 5.76 & 0.39 & 6.29 & 0.33 & 5.83 & 0.65 & 5.29 & 0.78 & 6.27 & 0.93\end{array}$ $\begin{array}{llllllllllllllll}5.52 & 0.19 & 5.89 & 0.24 & 5.96 & 0.28 & 6.17 & 0.23 & 6.30 & 0.47 & 5.82 & 0.56 & 6.80 & 0.66\end{array}$

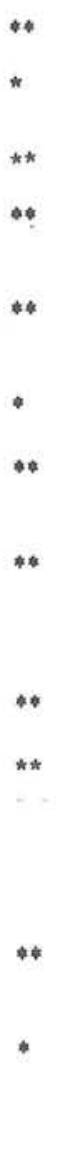

1) $\left.\left.n=213,{ }^{2}\right) n=212,{ }^{3}\right) n=211$ Error probability: $P<0.05,{ }^{\circ} P<0.01$

between judgements of individual classifiers could not be analysed. Still, the results of this first assessment of the external traits of the Old Kladrub Horse with the linear type system was quite an important step for the description, development and conservation of this breed. The classifiers also used for almost all traits the whole range of scores and thus captured all the variation present in this genetic resource population. Although, there is still room for further research, i.e. into differences between sire lines and dam families, into variation due to classifiers, into analysis of movements etc., a 
first and solid basis for selection decisions and the design of a specific breeding plan has been set.

Table 6

Significant interactions for traits (Signifikante Interaktionen für die Merkmale)

\begin{tabular}{|c|c|c|c|c|c|c|c|c|c|c|}
\hline $\begin{array}{l}\text { Type of } \\
\text { interaction }\end{array}$ & $\begin{array}{c}1 \\
\text { Height } \\
\text { at } \\
\text { withers }\end{array}$ & $\begin{array}{c}9 \\
\text { Topline } \\
\text { vault }\end{array}$ & $\begin{array}{l}10 \\
\text { Loin } \\
\text { length }\end{array}$ & $\begin{array}{c}13 \\
\text { Shoulder } \\
\text { shape }\end{array}$ & $\begin{array}{c}17 \\
\text { Chest } \\
\text { depth }\end{array}$ & $\begin{array}{c}20 \\
\text { Croup } \\
\text { width }\end{array}$ & $\begin{array}{c}21 \\
\text { Croup } \\
\text { shape }\end{array}$ & $\begin{array}{l}23 \\
\text { Tail } \\
\text { tethe- } \\
\text { ring }\end{array}$ & $\begin{array}{c}26 \\
\text { Bulki- } \\
\text { ness }\end{array}$ & $\begin{array}{c}28 \\
\text { Fore- } \\
\text { hoof- } \\
\text { side view }\end{array}$ \\
\hline VARXSEX & & & * & ** & & * & 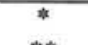 & * & * & \\
\hline $\begin{array}{l}\text { VARXAGE } \\
\text { SEXXAGE }\end{array}$ & $* *$ & ** & & & ** & * & $* *$ & & & ** \\
\hline
\end{tabular}

\section{References}

BILEK, F.: DUŠEK; J.:

The Old Kladrub Horse. (Czech Language). In: Speciálni zootechnika. II. Chov koní. Praha, Státní zemedelske nakladatelstvi (1955), 82-98

Conservation and exploitation of gene resources in horse breeding. (Czech Language). In: Uchovanie a vyuzitie genovych rezerv v chove hospodarskych zvierat. Sbornik AZV CSFR 159 (1992), 70-89

HARTMANN, O.; LENGERKEN, G. v.; SCHWARK, H.J.; BERGFELD, U.:

Linear description of conformation traits in riding horses. EAAP, Edinburgh, United Kingdom, 5 - 8 September 1994, 8 p.

HOLMSTRÖM, M.; MAGNUSSON, L.E.; PHILIPSSON, J.:

Variation in the conformation of Swedish Warmblood horses and conformational characteristics of élite sport horses. Equine Vet. Journ., 22 (1990), 186-193

JAKUBEC, V.; JELÍNEK, J.; VOLENEC, J.; ZÁLIŠ, N.:

Linear system of description and evaluation of body conformation for horses. Model application-Old Kladrub Horse. (Czech language). Hipologický vistník. National Stud Kladruby nad Labem, Czech Republic, 1 (1996), 5-32

KOENEN, E.P.C.; VELDHUIZEN VAN, A.E.; BRASCAMP, E.W.:

Genetic parameters of linear scored conformation traits and their relation with dressage and showjumping in the Dutch Warmblood Riding Horse population. EAAP, Edinburgh, United Kingdom, 5 - 8 September 1994, $20 \mathrm{p}$.

MAHRARENS, F.M.; SCHERTLER, H.:

Lineares Beschreibungssystem auch in der Pferdezucht. Der Tierzüchter, Hannover 39 (1987), 26-27

PREISINGER, R.; WILKENS, J.; KALM, E.:

Estimation for conformation traits for foals and their practical implications. Livest. Prod. Sci., Amsterdam 29 (1991), 77-86

SWALVE, H., FLOCK, D.:

Berücksichtigung von Beurteilermittelwert und Standardabweichung als wichtige Einflussgrössen bei der Analyse von Daten der linearen Exterieurbeschreibung. Züchtungskunde, Stuttgart 62 (1990), 367. 383

VAN BERGEN, H.M.M.; VAN ARENDONK, J.A.M.:

Genetic parameters for linear type traits in Shetland ponies. Livest. Prod. Sci., Amsterdam 36 (1993), 273-284 
WEYMANN, W.L.:

Zuchtwertschätzung für Exterieurmerkmale am Beispiel der Hannoverschen Warmblutzucht. GeorgAugust-Universität Göttingen, Ph.D. Thesis, 1992, 76 p.

Received: 16.07.1998

Accepted: 16.12 .1998

Author's addresses

Prof. VÁCLAV JAKUBEC, DrSc.

Czech University of Agriculture

Faculty of Agronomy

Department of Genetics and Animal Breeding

Kamýcká 129

16521 Prague 6

Czech Republic

Prof. Dr. WERNER SCHLOTE, Dr. ARMIN SCHOLZ

Humboldt-Universität zu Berlin

Institut für Nutztierwissenschaften

Lentzeallee 75

D-14195 Berlin

Germany

Dr. JAROSLAV JELfNNEK, MVDr. NORBERT ZÁLIŠ

National Stud at Kladruby nad Labem

53314 Kladruby nad Labem

Czech Republic 